\title{
37. LOW TEMPERATURE ALTERATION OF BASALTS PREDOMINATES AT DSDP SITE 395
}

\author{
J. R. Lawrence, Lamont-Doherty Geological Observatory of Columbia University, Palisades, New York \\ J. J. Drever, Department of Geology, University of Wyoming, Laramie, Wyoming \\ and \\ Miriam Kastner, Scripps Institution of Oceanography, La Jolla, California
}

\begin{abstract}
A variety of low temperature alteration products occur in the 573-meter-thick section of basaltic rock from Site 395. Carbonate veins, smectites (predominantly saponite), zeolites, goethite, opal, and gypsum, listed in order of decreasing abundance, are present. The only hiqher temperature mineral found was chlorite, and it occurs only in vesicles in two massive flows and a dolerite instrusive unit. Values of $\delta{ }^{18} \mathrm{O}$ (SMOW) of calcite veins range from +31.8 to $+34.8 \%$, and $\delta \mathrm{C}^{13}$ (PDB) ranges from +1.3 to $+3.8 \%$. Apparently the calcite veins were formed at $0^{\circ}-15^{\circ} \mathrm{C}$ in equilibrium with deep ocean water. Some veins may have formed during glacial periods when $\delta \mathrm{O}^{18}$ of the deep water was higher than it presently is. The deepest calcite veins were formed in the temperature range $8^{\circ}$. $15^{\circ} \mathrm{C}$. Three deep saponite veins $\left(\delta \mathrm{O}^{18}=+21.3\right.$ to $24.3 \%$, $\mathrm{SMOW}$ ) are estimated to have formed in the temperature range $30^{\circ}-45^{\circ} \mathrm{C}$. The presence of gypsum puts an upper temperature limit of its formation at $65^{\circ} \mathrm{C}$. The $\mathrm{Ca}^{+2}, \mathrm{Mg}^{+2}$, and $\delta \mathrm{O}^{18}(+0.4$ to $+0.6 \%$, SMOW) compositions of the pore fluids in the overlying sediments are in between those of present-day or glacial deep ocean waters. Overall, nearly all the alteration products found to date must have been formed in the presence of descending deep ocean water. Convective transport of the pore fluids in the basalts and large water/rock ratios are indicated.
\end{abstract}

\section{INTRODUCTION}

The idea that large-scale water circulation takes place through the ocean crust in the vicinity of midocean ridges is supported by heat-flow observations. The pattern of heat-flow values away from ridges fits conductive cooling models for oceanic lithospheric plates reasonably well, whereas near the ridges heatflow values deviate significantly, generally on the low side, from model values (cf. Wolery and Sleep, 1976; Anderson and Hobart, 1976). The general interpretation of this has been that convection of seawater in communication with overlying ocean takes place near the ridge.

Two important questions come to mind as a result of these observations. What chemical and isotopic interactions take place between seawater and the oceanic crust, and how does that change the chemical and isotopic compositions of both? How much heat transfer takes place, and how in detail does it occur? Wolery and Sleep (1976) thoroughly review the geophysical and geochemical studies completed in which these questions are asked.

The chemical and mineralogical changes that take place in the upper oceanic crust can in part be determined by studying the alteration products in the crust.
Quantitative estimates of chemical exchange can then be made. Isotopic analyses of both alteration products and pore fluids can be used to determine the temperatures of alteration, which in turn can bring definition to what temperatures are prevalent in the oceanic crust while it is in the vicinity of a ridge. This study represents the preliminary results of such an investigation at DSDP Site 395.

\section{DISCUSSION OF RESULTS}

A large variety of alteration products are present, principally in fractures and to lesser degree in vesicles in the basalts. Calcite veins occur throughout the section, along with chabazite, phillipsite, and goethite. Cores 60-67, taken from the base of the section, in the vicinity of a 20-meter-thick dolerite sill, contain abundant saponite as fracture fillings. Gypsum, opal, and chlorite are also present. Chlorite also occurs as a green filling in vesicles in massive flows from Cores 14 and 15. Bischoff and Dickson (1975) altered basalts under experimental conditions of $200^{\circ}$ and 500 bars pressure and produced dominantly montmorillonite and anhydrite.

The abundant fracture filling in Cores 60-67 is saponite, which varies in color from white to green, in tex- 
ture from granular to soapy, and in luster from dull to shiny. Table 1 contains chemical analyses of saponites from three separate horizons. As can be seen from these analyses, the green coloring appears to be related to iron content. The saponite was almost certainly formed as a result of heat-induced water circulation consequent to intrusion of the dolerite sill. If intrusions of this type are common in the oceanic crust, saponites may constitute an important sink for magnesium in the ocean's chemical budget.

Oxygen isotopic analyses of a large number of carbonate veins and the three chemically analyzed saponites are given in Table 2. Also given are the oxygen isotopic compositions of the pore fluids from the overlying sediments. The $\delta{ }^{18} \mathrm{O}$ values of the carbonates and calcite veins are very high, indicating formation at low temperatures. The $\delta{ }^{13} \mathrm{C}$ values are very restricted in range, and indicate formation of the veins from seawater. The pore fluids are enriched in ${ }^{18} \mathrm{O}$ with respect to Atlantic Deep Water $\left(\delta{ }^{18} \mathrm{O}=+0.12 \%\right.$, Craig and Gordon, 1965).

Figure 1 shows the temperature history of the sites as recorded by the alteration products. The temperatures derived from the calcite veins and the saponites were calculated assuming that the fluid was Atlantic Deep Water with a $\delta{ }^{18} \mathrm{O}$ of $+0.1 \%$. The calcite-water temperature relationship of O'Neil et al. (1969) was used for the temperatures of formation of calcite. The montmorillonite-water temperature relationship of Yeh and Savin (in press) was used to calculate temperatures from the isotope values of the saponites. Also shown is the temperature range of present-day Atlantic Deep Water. Two temperature regimes for the alteration products can be identified: a very cold regime associated with the upper calcite veins and a warm regime related to intrusion of the dolerite sill.

The calcite veins from 100 to 400 meters depth indicate formation at temperatures lower than any existing in present-day deep waters. The basalts were extruded onto the sea floor in the late Miocene, about 7 m.y. ago. The calcite veins may have formed as soon as the basalts completely cooled down to bottom-water temperatures, or they may have been formed at some later time closer to the present.

TABLE 1

Chemical Composition of Saponites, Hole 395A

\begin{tabular}{lccc}
\hline $\begin{array}{c}\text { Sample } \\
\text { Description }\end{array}$ & $\begin{array}{c}64-2,82 \mathrm{~cm} \\
\text { Green Vein }\end{array}$ & $\begin{array}{c}66-3, \\
\text { Piece \#12 } \\
\text { White Vein }\end{array}$ & $\begin{array}{c}60-2,80 \mathrm{~cm} \\
\text { Green Vein }\end{array}$ \\
\hline $\mathrm{SiO}_{2}$ & 49.7 & 51.4 & 50.6 \\
$\mathrm{~A}_{2} \mathrm{O}_{3}$ & 6.9 & 8.8 & 6.9 \\
$\mathrm{Fe}_{2} \mathrm{O}_{3} \mathrm{a}$ & 3.44 & 1.31 & 5.03 \\
$\mathrm{CaO}$ & 1.70 & 1.56 & 1.42 \\
$\mathrm{MgO}$ & 25.9 & 24.0 & 24.4 \\
$\mathrm{Na}_{2} \mathrm{O}$ & 1.68 & 2.16 & 1.83 \\
$\mathrm{~K}_{2} \mathrm{O}$ & 0.14 & 0.55 & 0.14 \\
$\mathrm{H}_{2} \mathrm{O}^{\mathrm{a}}$ & - & - & $9 \pm 0.5$ \\
\hline
\end{tabular}

${ }^{\mathrm{a}}$ Total Fe.
TABLE 2

Oxygen and Carbon Isotope Data From Site 395

\begin{tabular}{|c|c|c|c|c|c|c|}
\hline \multirow{2}{*}{$\begin{array}{c}\text { Sample } \\
\text { (Interval } \\
\text { in } \mathrm{cm} \text { ) }\end{array}$} & \multirow[b]{2}{*}{$\begin{array}{c}\text { Piece } \\
\#\end{array}$} & \multirow[b]{2}{*}{$\begin{array}{l}\text { Depth } \\
\text { (m) }\end{array}$} & \multirow[b]{2}{*}{$\begin{array}{c}\delta^{18} \mathrm{O} \\
\text { (SMOW) }\end{array}$} & \multirow[b]{2}{*}{$\begin{array}{l}\delta^{13} \mathrm{C} \\
\text { (PDB) }\end{array}$} & \multicolumn{2}{|c|}{$\begin{array}{c}\text { Temperature } \\
\left({ }^{\circ} \mathrm{C}\right)\end{array}$} \\
\hline & & & & & $\begin{array}{l}\text { Non- } \\
\text { glacial }\end{array}$ & Glacial \\
\hline \multicolumn{7}{|c|}{ Calcite Veins ${ }^{\mathrm{a}}$} \\
\hline Hole 395 & & & & & & \\
\hline $18-2,11-15$ & 2 & 161.26 & +34.55 & +2.76 & 0.0 & 4.5 \\
\hline $18-2,14-16$ & 3 & 161.28 & +33.92 & +4.39 & 2.2 & 6.8 \\
\hline $18-2,22-24$ & 4 & 161.38 & +34.08 & +4.09 & 1.6 & 6.2 \\
\hline $18-2,26-30$ & 5 & 161.41 & +34.06 & +3.67 & 1.7 & 6.3 \\
\hline $18-2,58-60$ & 14 & 161.72 & +33.87 & +4.04 & 2.4 & 7.0 \\
\hline $18-2,140-142$ & $17 \mathrm{G}$ & 162.54 & +33.72 & +3.81 & 3.0 & 7.6 \\
\hline $19-1$ & 2 & 162.77 & +33.62 & +3.42 & 3.3 & 8.0 \\
\hline \multicolumn{7}{|l|}{ Hole 395A } \\
\hline $15-3,26-28$ & 16 & 195.66 & +34.43 & +3.31 & 0.4 & 4.9 \\
\hline $15-4,123-126$ & $1 \mathrm{~N}$ & 198.13 & +34.02 & +2.94 & 1.9 & 6.5 \\
\hline $22-1,121-125$ & $13 \mathrm{E}$ & 253.10 & +34.14 & +3.23 & 1.4 & 6.0 \\
\hline $22-2,25-33$ & 10 & 253.66 & +33.33 & +2.27 & 4.4 & 9.1 \\
\hline $26-1,129-133$ & $11 \mathrm{~B}$ & 290.99 & +34.10 & +3.55 & 1.6 & 6.2 \\
\hline $27-1,120-123$ & $2 \mathrm{~A}$ & 300.44 & +34.40 & +3.72 & 0.5 & 5.0 \\
\hline $32-1,54-56$ & $3 \mathrm{~A}$ & 345.91 & +34.41 & +2.91 & 0.5 & 5.0 \\
\hline $32-1,118-119$ & & 346.55 & +34.75 & +3.97 & -0.7 & 3.7 \\
\hline $32-2,28-30$ & & 347.15 & +33.93 & +3.06 & 2.2 & 6.8 \\
\hline $32-2,65-66$ & & 347.51 & +34.76 & +2.81 & -0.8 & 3.7 \\
\hline $52-1,114-120$ & 9 & 534.31 & +32.33 & +3.05 & 8.2 & 13.1 \\
\hline $55-1,118-126$ & 8 & 553.14 & +32.03 & +3.06 & 9.4 & 14.4 \\
\hline $61-2,98$ & 7 & 611.28 & +32.21 & +3.56 & 8.7 & 13.6 \\
\hline $63-4,80-88$ & $1 \mathrm{E}$ & 624.87 & +30.81 & +3.00 & 14.3 & 19.6 \\
\hline \multicolumn{7}{|c|}{ Saponites ${ }^{\mathrm{b}}$} \\
\hline \multicolumn{7}{|l|}{ Hole 395A } \\
\hline $60-2,80-86$ & & 600.86 & +24.3 & & $32 \pm 5$ & \\
\hline $64-2,82$ & & 628.45 & +21.4 & & $48 \pm 5$ & \\
\hline $66-3,125$ & 12 & 649.42 & +21.3 & & $49 \pm 5$ & \\
\hline \multicolumn{7}{|c|}{ Pore Waters ${ }^{\mathrm{a}}$} \\
\hline \multicolumn{7}{|l|}{ Hole 395} \\
\hline $3-5,140-150$ & & 24.8 & $+0.4 \pm 0.2$ & & & \\
\hline $5-5,140-150$ & & 43.9 & $+0.6 \pm 0.1$ & & & \\
\hline $7-3,140-150$ & & 59.7 & $+0.6 \pm 0.3$ & & & \\
\hline $9-5,140-150$ & & 81.7 & $+0.5 \pm 0.3$ & & & \\
\hline
\end{tabular}

${ }^{a}$ The water standard NBS-1 was used as the primary running standard for $\delta^{18} \mathrm{O}$ used to calibrate the mass spectrometer standard gas for $\delta 18 \mathrm{O}$ (Craig, 1961). The $\mathrm{CO}_{2}-\mathrm{H}_{2} \mathrm{O}$ curve of Bottinga and Craig (1969) was used to calibrate the mass spectrometer standard gas for $\delta^{18} \mathrm{O}$. The temperature relationship of O'Neil et al. (1969) was used to calculate the calcite temperatures. The nonglacial temperatures were calculated assuming equilibration with a water having $\delta 18 \mathrm{O}(\mathrm{SMOW})=+0.1 \% \circ$ (Craig and Gordon, 1965), the glacial temperatures with a water having $\delta 18 \mathrm{O}=+1.3 \%$ o. NBS-20 was used as the primary running standard for $\delta^{13} \mathrm{C}$ analyses (Craig, 1957).

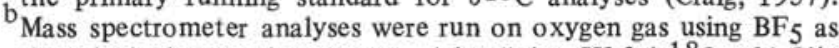
the principal extraction reagent. A kaolinite, SK- $3\left(\delta_{1} 18 \mathrm{O}+21.5 \%\right.$ o [SMOW]) calibrated against the Cal Tech standard Rose Quartz was used as the primary running standard. The temperature relationship for montmorillonite-water of Yeh (1974) was used to calculate the saponite temperatures.

The calcites having the highest $\delta{ }^{18} \mathrm{O}$ values seem to have formed either at near-zero bottom water temperatures or in a water enriched in ${ }^{18} \mathrm{O}$ compared to today. The only time the $\delta{ }^{18} \mathrm{O}$ values of sea water have been higher has been during periods of glacial advances. Such advances have predominated in the last two million years. A reasonable limit for an increase in the $\delta$ 

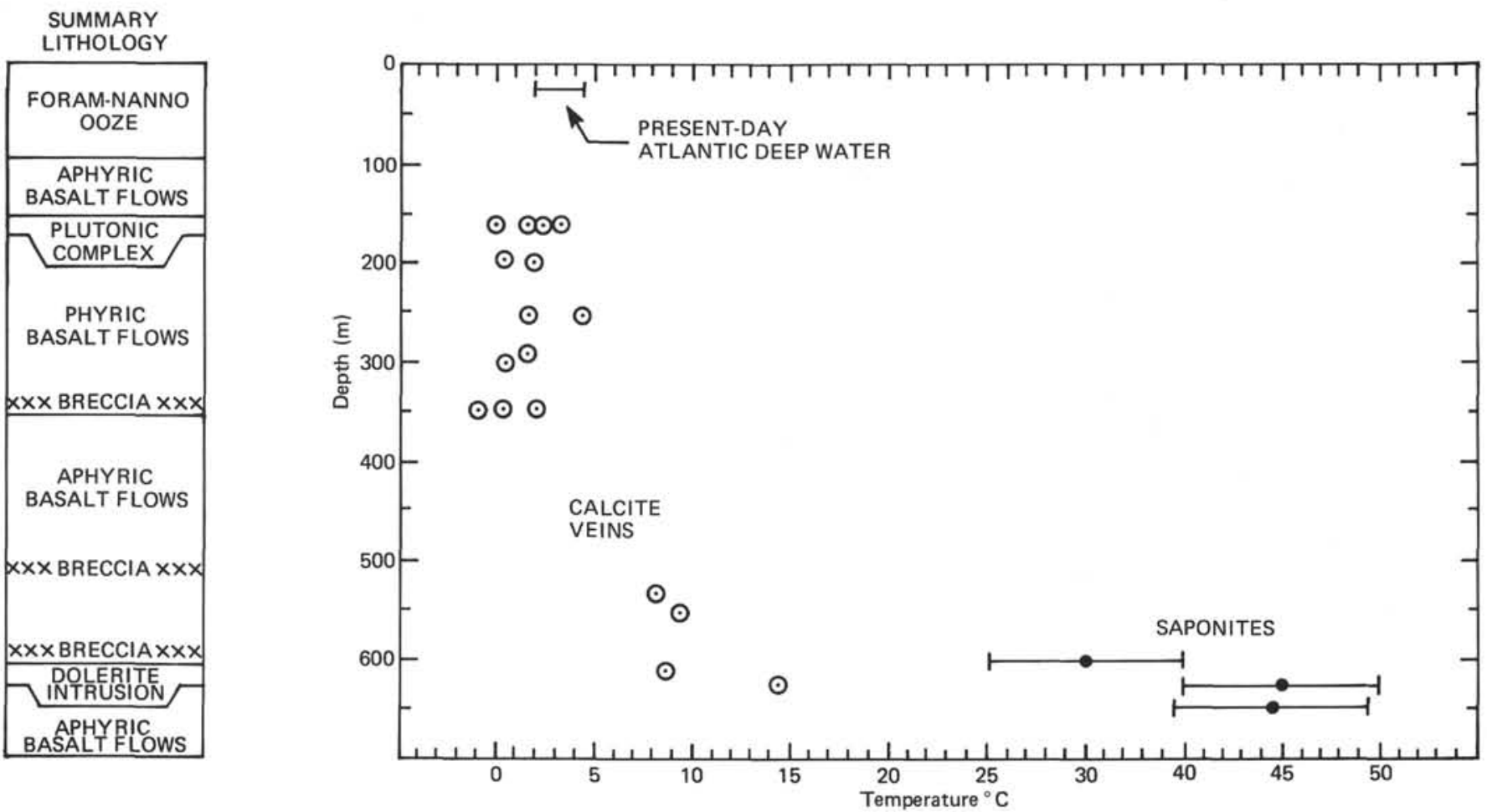

Figure 1. The temperatures of formation of calcite veins (see Table 2) are shown. The calculations were made assuming formation is isotopic equilibrium with Atlantic Deep Water $\left(\delta^{18} \mathrm{O}=+0.1 \%\right.$, Craig and Gordon, 1965). The temperatures were calculated using the temperature relationship for calcite-water of O'Neil et al. (1969). The temperatures of formation of the saponite veins (see Table 2) are also shown. Yeh's (1974) temperature relationship for montmorillonite-water was used. The temperature range for present-day Atlantic Deep Water is also shown. The lithology of the sediment and basalt stratigraphic column are given.

${ }^{18} \mathrm{O}$ of the oceans is about $1.2 \%$. Calcites forming in such water and having the $\delta{ }^{18} \mathrm{O}$ values of Table 2 would yield temperatures of 4 to $5^{\circ} \mathrm{C}$ higher (see Table 2) than shown in Fig. 1, placing them in the region of bottom water temperatures.

Shackleton and Kennett (1974) indicate bottom water temperatures since late Miocene have always been similar to those found today. If this is so, then the calcite veins in the upper basalts appear to have formed or recrystalized during a glacial advance. Formation at any time other than a time shortly after the extrusion of the basalts implies extensive cold water circulation in the oceanic crust.

That deep water enriched in ${ }^{18} \mathrm{O}$ may have been circulating through the basalts over the last two million years is also suggested by the $\delta{ }^{18} \mathrm{O}$ values of the pore waters in the sediments. For most of the history of the site 2.5-7 m.y.B.P., $\delta{ }^{18} \mathrm{O}$ of the deep waters was probably like present-day values (Schackleton and Kennett, 1974). Water entrapped in most of the sediments would have had a $\delta{ }_{18} \mathrm{O}$ value near $+0.1 \%$. During the last two million years that water therefore had to be replaced by deep water enriched in ${ }^{18} \mathrm{O}$. This probably means circulation at rates greater than simple diffusion-i.e., convective transport. This convective transport must have been slow enough, however, that the high $\delta{ }^{18} \mathrm{O}$ values of the pore waters were not wiped out over the last 10,000 years. The waters over this latest period have also had a $\delta 180$ value of $+0.1 \%$.

When the dolerite was intruded it produced a considerable degree of warm-water alteration. The presence of gypsum puts an upper limit of $65^{\circ} \mathrm{C}$ on the temperature. The saponite above the sill gives a temperature of $30^{\circ} \mathrm{C}$, whereas those saponites in and below the sill indicate temperatures of about $45^{\circ} \mathrm{C}$. The calcite veins yield temperatures of $8^{\circ}-15^{\circ} \mathrm{C}$. They were probably formed or recrystallized at a late stage during the cooling of the sill. The paleomagnetic data (P. Johnson, personal communication) suggest that the basalts below the sill but not above it were reversely magnetized during the hydrothermal event. The temperatures of formation of the saponites above the sill are lower, $\sim 32^{\circ} \mathrm{C}$, compared to those in and below it, $\sim 48^{\circ} \mathrm{C}$. This suggests that remagnetization is more likely to have occurred below the still than above.

\section{ACKNOWLEDGMENTS}

We are grateful to the numerous people involved in the drilling and sampling program of the Deep Sea Drilling Project aboard Glomar Challenger. This research was directly supported by the National Science Foundation through Grant OCE-75-02968 to Lamont-Doherty Geological Observatory and Grant GA-33503 to the University of Wyoming, and indirectly through its support of the Deep Sea Drilling Project. 


\section{REFERENCES}

Anderson, R. N. and Hobart, M. A., 1976. The relationship between heat flow, sediment thickness, and age in the eastern Pacific: J. Geophys. Res., v. 81, p. 2968-2989.

Bischoff, J. L. and Dickson, F. W., 1975. Seawater-basalt interaction at $200^{\circ} \mathrm{C}$ and 500 bars: implications for origin of seafloor heavy-metal deposits and regulation of sea-water chemistry: Earth planet, Sci. Lett., v. 25, p. 385-397.

Bottinga, Y. and Craig, H., 1969. Oxygen isotope fractionation between $\mathrm{CO}$ and water and the isotopic composition of marine atmospheric $\mathrm{CO}_{2}$ : Earth Planet. Sci. Lett., v. 5. p. 285-295.

Craig, H., 1957. Isotopic standards for carbon and oxygen and connection factors for mass spectrometer analysis of carbon dioxide: Geochim. Cosmochim. Acta, v. 12, p. 133149.

1961. Standard for reporting concentrations of deuterium and oxygen-18 in natural waters: Science, v. 133 , p. $1833-1834$.

Craig, H. and Gordon, L., 1965. Deuterium and oxygen 18 variations in the ocean and marine atmosphere. In Ton- giongi, E. (Ed.), Stable isotopes in oceanographic studies and paleotemperatures: Spoleto Conf., v. 9.

O’Neil, J. R., Clayton, R. N., and Mayeda, T. K., 1969. Oxygen isotope fractionation in divalent metal carbonates: $J$. Chem. Phys., v. 51, p. 5547-5558.

Shackleton, N. J. and Kennett, J. P., 1974. Late Cenozoic oxygen and carbon isotopic changes at DSDP Site 284: Implications for glacial history of the Northern Hemisphere and Antartica. In Kennett, J. P., Houtz, R. E., et al., Initial Reports of the Deep Sea Drilling Project, v. 29: Washington (U.S. Government Printing Office), p. 801807.

Wolery, T. J. and Sleep, N. H., 1976. Hydrothermal circulation and geochemical flux at mid-ocean ridges, J. Geol.,v. 84 , p. $249-275$.

Yeh, H. W., 1974. Oxygen isotopic studies of ocean sediments during sedimentation and burial diogenesis, Ph.D. Thesis, Case Western Reserve Univ.

Yeh, H. W. and Savin, S. M., in press. Mechanism of burial metamorphism of argillaceous sediments: O-isotope evidence, Geol. Soc. Am. Bull. 